\title{
Liberalism: Impact on Social Science
}

Richard Bellamy

Professor of Political Science UCL, London University and Director of the Max Weber Programme, European University Institute, Florence

(NB Contact details, but may change after 1 May 2014)

Department of Political Science

School of Public Policy

University College London

29/30 Tavistock Square

London WC1H 9QU

Tel: +44 (0) 2076794980

Fax: +44 (0) 2076794969

Mobile 07763174423

email: r.bellamy@ucl.ac.uk

\begin{abstract}
A doctrine with roots in eighteenth century thought, liberalism emerged in the nineteenth century as the prevailing ideology of Western capitalist societies and democracies. Philosophically, liberalism consists of a commitment to the ideals of equality, liberty, individuality, and rationality. However, liberals have divided over their social and political implications. Some liberals have believed these values to be inscribed within the very fabric of modern societies, reflecting the innovative technologies, social differentiation and free movement of labor, goods, and capital characteristic of the commercial and industrial age and its aftermath. Others have thought the links between the two are fortuitous and contingent, and that these and other related social changes, such as the growth of bureaucracy, potentially threaten liberalism. Politically united against traditional and hierarchical societies, liberals have differed, therefore, over
\end{abstract}


whether liberalism requires various kinds of political support, such as the state regulation of markets, or merely the absence of any interference by either the state or others to the spontaneous and autonomous social activities of individuals. Meanwhile, critics of liberalism have either blamed it for all contemporary social ills or regarded it as a transitory phase to be replaced by superior forms of social organisation. However, contemporary liberals seem increasingly critics themselves of the inequality and abuse of rights found in modern societies, although how far their proposals can be made a reality remains uncertain.

Key words: liberty, equality, rights, justice, democracy, markets

A doctrine with roots in eighteenth century thought, liberalism emerged in the nineteenth century as the prevailing ideology of Western capitalist societies and democracies. Though much transformed by the social and political developments of the twentieth century and seriously challenged by the various movements associated with them, especially fascism and socialism in the first half of the century and feminism, ecologism, and multiculturalism in the second, liberalism has retained its dominant place. It combines philosophical, social, and political elements. Philosophically, liberalism consists of a commitment to the ideals of equality, liberty, individuality, and rationality. However, liberals have combined these concepts in numerous and often opposed configurations, which reflect different social assumptions. Many liberals have believed these values to be inscribed within the very fabric of modern societies, reflecting the innovative technologies, social differentiation, and free movement of labor, goods, and capital characteristic of the commercial and industrial age and its aftermath. Others have thought the links between the two are fortuitous and contingent, and that these and other related social changes, such as the growth of bureaucracy, potentially threaten liberalism. Politically united against traditional and hierarchical societies, liberals have differed, therefore, over whether liberalism requires various kinds of political support, such as the state regulation of markets, or merely the absence of any interference by either the state or others to the spontaneous and autonomous social activities of individuals. Meanwhile, critics of liberalism have either blamed it for all contemporary social ills, or regarded it as a transitory phase to be replaced by superior forms of social organization. Liberalism has featured in social science in correspondingly 
divergent ways: as the 'natural' value system of modern societies, as a historically and culturally specific phase of social development, as either pernicious or expressive of basic human goods.

\section{Liberalism Defined}

For analytical purposes it is convenient to break liberalism down into its philosophical, social, and political components, though these form a package that different liberals have interpreted in diverse ways.

\subsection{Liberal Philosophy}

At a philosophical level, liberals seek the maximal equal liberty possible for all individuals to rationally and freely choose and realize their various projects and preferences without interfering with each other. This position draws together the concepts of equality, liberty, individuality, and rationality in a distinctive way. Liberals value equality in the sense of denying that anyone is the natural subordinate of others. This view does not entail regarding people as the same, merely that everyone has equal moral worth. Instead of seeking equality of outcome like certain socialists, liberals simply desire that all should have an equal opportunity to deploy what talents they do possess on the same basis as everyone else. Their attachment to liberty follows from this interpretation of equality and its implicit endorsement of the moral primacy of the individual. Among moral equals, individuals should be allowed to pursue their own good in their own way to the extent that is compatible with a like liberty for others. Finally, as rationalists, liberals believe that individuals should behave in a coherent and consistent manner and that decisions in the public domain should be open to critical scrutiny and amendment and capable of attaining the reasoned assent of those they affect (see Freedom/Liberty: Impact on the Social Sciences). Though liberals share a moral ethos and broadly agree on the conceptual relationships between liberalism's core values, they offer very different interpretations of them reflecting a wide variety of epistemological and ontological perspectives. Thus, liberals include methodological individualists such as Adam Smith or Herbert Spencer and holists such as Emile Durkheim, materialists such as John Locke and idealists such as T. H. Green or Benedetto Croce, utilitarians such as J. S. Mill and natural rights theorists such as Tom Paine, abstract universalists such as Kant, and historicist relativists such as Herder, and so on. Moreover, their main practical differences stem less from these considerations than from contrasting social visions and political 
judgements. Though individual thinkers naturally relate these last to their particular metaphysical and methodological views, the connections between them are far from clear cut. Similar theoretical perspectives often generate quite different practical stances, while thinkers of quite diverse theoretical positions may often be in substantial practical agreement.

\subsection{Liberal Society}

Historically, the most significant social influence on the formation of liberalism was the passage from feudalism to capitalism from the sixteenth to the nineteenth century. This fuelled the liberal attack on ascribed status and its commitment to equality of opportunity. The closed feudal order of inherited rights, with its hierarchical system of aristocratic privileges, was to give way to an open and egalitarian capitalist order, in which an individual's social position and success supposedly mirrored his or her ability and effort - a way of life they felt was best realized in a free market economy.

Some contemporary liberals and many of liberalism's critics regard the ethos resulting from such social origins as essentially materialist, instrumental, and egoistic. Traditionally, however, liberals have been extremely wary of such attitudes and have sought to avoid them. The liberal conception of economic behavior emerged from the experience of the entrepreneurs, traders, shopkeepers, and artisans of early capitalism, and invokes the image of an idealized market order in which rewards are closely linked to effort. This linkage was codified in the labor theory of value and, in the British and North American context at least, drew additional support from the religious beliefs of certain Protestant sects that encouraged industriousness as a mark of salvation. The market also acts as a discovery mechanism, with competition and the profit motive weeding out bad practices and poor products whilst stimulating the search for new processes and commodities, and so promoting the progress of society.

Liberals have disagreed, however, over how far a policy of laissez-faire can secure these advantages, and doubts have grown as capitalism has taken on a more corporate form. Most have accepted the need for some regulation to protect the market against itself and maintain its freedom - such as anti-trust and monopolies legislation. Others have sought to distinguish between the economic and social disadvantages that individuals are responsible for and those they are not, supporting quite extensive unemployment insurance and state-supported training schemes, for example, to get the unintentionally out of work back into jobs. Finally, liberals have 
always acknowledged certain public goods will be badly provided or even neglected by market mechanisms, even if some have believed state provision could employ market elements such as competitive tendering - defense and certain infrastructural goods, such as light-houses, were the classic cases. Clean air, education, and a health service serve as more recent and contentious examples.

\subsection{Liberal Politics}

The political face of liberalism follows on from the philosophical and social elements outlined above but was additionally influenced by the wars of religion and the rise of modern science in the sixteenth and seventeenth centuries, which fuelled calls for religious toleration and the related belief in rationalism and the moral equality of individuals. Along with the shift from social structures based on status to contractual relations between civic equals, these commitments led to the demand that politics reflect liberal principles. The state, like society as a whole, came to be seen as a voluntary association held together by the mutual consent of its members rather than the ties of deference to social superiors - a conception of political order summed up in the theory of the Social Contract.

The basic components of a liberal political system were established in the wake of the British, American, and French revolutions of 1688, 1776, and 1789, respectively. All three gave rise to new constitutional settlements and bills of rights. Two criteria informed these arrangements. First, laws were to be framed and applied impartially and universally. There were to be no special exemptions for particular groups, such as clerics and nobles, as in the past. Second, the laws were to guarantee to the greatest extent possible the equal right of each individual to pursue their own plan of life. For the majority of liberals, the most basic rights in this respect were traditionally the rights to private property and freedom of belief. These rights were essential to their understanding of the virtues of the market mechanism and of toleration, which they regarded as the embodiments of the new ethos.

At the heart of liberal politics is a distinction between the state and civil society (see State and Society). The purpose of the state is to facilitate social interaction rather than to substitute for individual initiative through state control of social institutions. The latter is the mark of dictatorships in liberal eyes. However, social liberals nevertheless believe economic intervention and state provision of certain social goods can have an enabling role, though market liberals 
contend such steps undermine liberalism. Liberals are also often said to favor a related distinction between the public and private sphere, allowing behavior in the latter they would ban or restrict in the former. However, this distinction has never come out cleanly. To the extent liberals do distinguish between the two it is as a corollary of their views of the state's role in regulating society. The marriage contract, for example, offers a quintessential liberal device of a public character with a clear impact on private behavior. Just as liberals of different hues dispute the degree to which workers are free to sell their labor and the extent to which a valid contract implies certain standards of pay and conditions, so they have also debated whether and in what ways the marriage contract constrains the behavior of couples and grants women, in particular, rights to common property and protection against rape and abuse.

We have already disputed the view of liberalism as promoting possessive individualism in the socioeconomic sphere. A related objection contends that liberals advocate subjectivism, skepticism, and relativism in the political sphere, with all views treated as little more than personal opinions. However, the liberal insistence on the individual's right to follow his or her own path does not entail regarding all ways of life as equally valuable. Drawing on the experimental method in modern science and the Protestant defense of freedom of conscience, liberals contend that truth and morality emerge through individuals being allowed to call into question accepted doctrines and try out new and occasionally eccentric or potentially offensive pursuits. Ideas have to be tested for their validity while personal virtue only comes from our taking responsibility for our lives. For the state or any group to paternalistically impose its views on the rest of society risks falling into dogmatic error, demoralizes the population, and produces stagnation. Individuals must be able to make mistakes so that they can learn from them and emerge morally and materially improved.

Nevertheless, liberals have seen no need to tolerate the 'intolerable,' defined as views that are incompatible with treating others as moral equals. Some critics have regarded this position as inconsistent with liberalism's claims to openness. Yet certain limits are clearly implicit in liberalism and would otherwise render it incoherent. Where exactly these boundaries lie and their legitimacy and justifiability are more contentious matters, however. Liberalism has been accused of a gendered, imperialist, and Euro-centric bias, and historically this has often been the case, albeit to differing degrees and with certain important if qualified exceptions, such as J. S. Mill's attack on the Subjection of Women. How far gender and multiculturalism remain a blind spot is 
less clear. Many contemporary liberals maintain that multicultural, gay, and feminist demands for recognition and respect, like other appeals against unjust discrimination, implicitly invoke liberal norms of equality and tolerance. They have simply revealed these principles to have a broader application than certain past liberals had appreciated.

The complexities of the liberal position emerge when we consider their ambivalent view of democracy. Liberals have recognized that democracy offers a means for holding governments to account, obliging policies to be justified and improved through critical debate, and allowing politicians to be peacefully removed when they prove incompetent, biased, or corrupt. However, past liberals sought to limit political citizenship to those with the intellectual attainment and economic resources they believed were required for 'independent' rational decision makingcriteria that usually had the effect of ruling out workers and women. Even so, liberals worried about the 'tyranny of the majority' as represented by an irrational and dependent mass, whose votes could be bought by unscrupulous populists willing to pander to their prejudices and interests. As a result, liberals have tended to insist on the need for constitutional safeguards to protect liberal values from being overturned by democratic decisions.

\section{Liberalism and Modern Society}

Social scientists have seen liberalism as either an inherent and defining characteristic of modernity or as threatened by it. Amongst the first camp, moreover, there are those who see it as symptomatic of modernity's ills rather than its advantages, identifying liberalism with a possessive individualism that is not only antisocial but anti sociological as well.

\subsection{Liberalism as the Ethos of Modernity}

The view of liberalism as the ethos of modernity was best expressed by British social scientists such as Adam Smith, Herbert Spencer, J. S. Mill, T. H. Green, and L. T. Hobhouse, and to a lesser extent French thinkers such as Benjamin Constant, Francois Guizot, and Emile Durkheim. For these thinkers, liberalism's philosophical commitment to expanding equal individual liberty was underwritten by a theory of social evolution whereby potential conflicts between different liberties would be harmonized. This latter thesis idealized the market relations between smallscale entrepreneurs characteristic of early capitalism. These were taken as a model of a meritocratic society of self-reliant and responsible citizens, who freely contract with each other 
for mutual advantage. Liberal politics was conceived as the superstructural products of these social and economic changes. Freedom, reason, morality, and progress came in this way to be identified, with an optimistic account of social development supporting an implicitly ethical naturalist philosophical belief in the compatibility of different forms of self-realization.

Adam Smith's doctrine of the 'invisible hand' of the market and Herbert Spencer's characterization of the 'industrial' form of organization as realizing the 'Law of Equal Freedom' offer classic examples of this position. The first a product of the commercial society of the eighteenth century, the second of the early industrial age of the 1840s, by the late nineteenth century the concentration of capital and the rise of organized labor had made liberals rather less sanguine about the inevitability of their vision. To the dismay of Spencer and other adherents of the earlier 'classical' liberalism, liberals began to envisage a more proactive role for the state in sustaining favorable social conditions. T. H. Green and L. T. Hobhouse, for instance, saw policies such as factory hours regulation and unemployment insurance as mechanisms for promoting freedom of contract and freeing individuals from certain structural constraints. Importantly, though, both saw the state as reducing the mutual interferences between individuals and fostering autonomy. In a similar manner, Durkheim argued that the liberal 'cult of the individual' was inherent to industrial societies and that the modern division of labor fostered an organic solidarity between autonomous agents. However, he had to confront various commercial crises, bankruptcies, and conflicts between capital and labor that suggested a less harmonious picture. He attributed these disturbances to contemporary societies being in a 'transitional phase' in which people had yet to fully assimilate liberal social norms. He too saw a role for the state in fostering these attitudes, with various 'intermediary institutions' serving to inform state policies as to social needs and act as a counter weight to state oppression of the individual (see Social Question: Impact on Social Thought).

Critics of liberalism sometimes portray this supposed relationship between liberalism and modernity in negative terms. They associate liberalism with a naturally instrumental and individualist model of human behavior, a disposition they believe is encouraged by the liberal conception of the market and democracy. They also claim it produces a view of social science as following the physical sciences by elaborating general laws of social development on the basis of various constant human passions. Some commentators have even argued that it was only radical and conservative opponents of liberalism who appreciated the distinctiveness of the human 
sciences by noting, respectively, how human behavior was modified by social structures and by culture, and the capacity of individuals to interpret and evaluate circumstances in different ways. At best, liberalism results in a positivistic bourgeois ideology that ignores the impact on human thought and action of material conditions and productive forces, historically evolving communal traditions and conventions, and the possibility for reflective criticism. Thus liberalism is associated with certain behaviorist versions of political science and economics but not with sociology or anthropology. These arguments result from a highly selective and tendentious reading of the liberal tradition whereby, for example, De Tocqueville becomes a 'conservative,' Durkheim either a 'conservative' or a 'socialist,' and Herbert Spencer, read as an advocate of egoistic possessive individualism, becomes the exemplar of liberal social science. The liberal tradition, however, is much more diverse than this caricature, both methodologically and substantively. The vast majority of liberals distinguished respect for 'individuality' from 'egoism' and even positivist behaviorists, such as J. S. Mill, appreciated that autonomy only flourished given certain material conditions, cultural values, and economic structures and played a part in its turn in how these were fashioned in the future. This awareness of the social and historically contingent character of liberalism is no more evident than in those liberals who saw it as being undermined by modernity.

\subsection{Liberalism as Threatened by Modernity}

The threat posed to liberalism by elements of modernity was especially evident in countries such as Italy and Germany, where a modernizing economy and society went along with fragile and incomplete liberal regimes which ultimately succumbed to fascism. The challenge these developments posed for liberal social science is powerfully illustrated by the 'frustrated' liberalism of the Italian Vilfredo Pareto and the 'disenchanted' liberalism of Weber. Though commonly categorized as sociologists, their work ranges over the whole gamut of the social sciences, covering economics, politics, and, in Pareto's case, social psychology. Pareto was in many respects a sophisticated exponent of the instrumentally rational actor model of liberal individualism and was initially a strong advocate of both laissez-faire economics and a libertarian and democratic politics. However, he became convinced that what he called 'logicoexperimental' thinking was the exception rather than the rule. Instead, most conduct was 'nonlogical' and arose from certain common psychological dispositions of either a conservative 
or more inventive kind. Politics simply consisted of the manipulation of these psychic states, a process that had been greatly aided by contemporary mass democracy. The electorate was too large and poorly informed and the decisions needed too numerous and diverse for rational debate to be possible. Democracy simply allowed populist leaders to legitimize their rule via emotive appeals to a popular will that was largely of their own making. He even briefly supported fascism as a possible way of breaking free from this system and establishing a liberal market order from above.

Weber, by contrast, offered a more historically and sociologically nuanced account of similar phenomena. He disputed that economic development per se fostered liberalism or that liberal values could be justified a priori. Liberalism's apparent basis in natural law had been historically contingent, reflecting the peculiar social and political experiences of early modern Europe outlined above. Not only was this constellation of factors unlikely to reappear, but even within established liberal regimes liberalism was threatened by the spread of economic instrumentalism, bureaucratic rationality, and corporate organization resulting from the further development of capitalism. The chances of liberal democracy being established in societies such as Russia, which had not benefited from the earlier favorable historical experiences, were minimal, therefore. Quite different cultural values were likely to shape the modernizing processes of such societies, as indeed has occurred throughout Asia where capitalism has by and large taken a nonliberal form. Meanwhile in already existing liberal societies, the autonomous action characteristic of liberalism was possible only for the political leaders and entrepreneurs who controlled and gave direction to the various political and economic administrative structures that govern our lives (see Modernity).

Most contemporary liberal thinkers regard Weber as too pessimistic and many believe liberal values can be justified on grounds distinct from their historical and social origins. However, the possible disjunction between late modernity and liberalism, on the one hand, and the search for liberal foundations that appeal to reasons that ought to be accessible to all and so compatible with a variety of different cultures and ideals, on the other, remain the prime challenges a viable liberal theory has to meet.

\section{Contemporary Liberalism}


Contemporary liberal philosophers have sought to overcome the Weberian challenge by seeking to divorce liberal principles from controversial ethical, epistemological and ontological viewpoints. They argue that the chief advantage of liberal theories of the market, democracy and justice resides in letting people holding different moral and material priorities and preferences live peaceably and profitably together. However, in spite of this agreed approach, these theorists split along the main ideological divisions of the contemporary world. The gradual electoral drift of liberals to social democracy, on the one hand, and conservatism, on the other, has been reflected in a parallel division in contemporary liberal philosophy between social democratic and New Right, neo-liberal theorizing. I shall briefly examine an example of liberal thinking from both these camps.

\subsection{Liberalism between Social Democracy and Neo-Liberalism}

The major exponent of contemporary social democratic liberalism is John Rawls (1921- 2002), whose A Theory of Justice (1972) is probably the most important work of political philosophy written in English since the Second World War. Rawls uses the classical liberal device of a social contract to arrive at two principles of justice which he believes will serve to regulate the relations between individuals within modern societies. He asks us to imagine which principles we would choose to adopt if we knew neither what sort of person we were or the precise circumstances of the society we might be born into. All we know are certain general facts about human psychology, sociology, economics and politics.

Rawls believes that this thought experiment, which he elaborates in great detail, will produce a theory of justice that everyone will accept as legitimate because it is untainted by any preconceptions about the owrth or lack of it of particular beliefs or ways of life. Rather, we shall be drawn to appreciate the value of showing equal concern and respect to all people, regardless of their views. For, faced with the radical uncertainty of what Rawls calls the 'original position', we will seek to arrive at principles of justice that are as fair as possible to all persons whatever their talents or ideals might be. Indeed fairness, rather than truth or goodness, is the only acceptable criterion of modern justice for Rawls. 
What then are Rawls' two principles, and what kind of policies do they require for their realization? According to the first principle, the state must provide the most extensive system of equal liberties possible. All individuals must enjoy the greatest degree of liberty consistent with the enjoyment of a like liberty by everyone else. According to the second principle, there must be equal opportunity to obtain positions and status in society, regardless of colour, gender, or creed. To help achieve this goal, each person is to have an equal share of wealth except when an unequal distribution would improve the welfare of the least well-off in society, by providing incentives that encourage people to work harder and produce more in ways that raise the living standards of everyone. Even so, a progressive taxation policy would be necessary if the trickledown effect failed to produce any benefits from this greater affluence for those at the bottom of society. Like earlier social liberals, such as Hobhouse or Durkheim, therefore, Rawls tries to combine the liberal values of liberty and equality with a concern for social justice tempered, in characteristic social-liberal fashion, by the requirements of efficiency. Unlike earlier social liberals, however, he has sought to dissociate his argument for these policies from the traditional liberal ethos and metaphysics.

Three years after Rawls' book appeared, Robert Nozick (1938-2002) published Anarchy, State and Utopia (1974) defending the market and a minimal state and criticizing any form of welfarist policy on libertarian grounds. He argues that any attempt to redistribute resources or to intervene in the economy involves an illegitimate attempt to use people to further some social purpose with which they may not agree. On his view, the advantage of the market is that it reflects no particular conception of the good, the resulting distributions being merely the unplanned consequence of numerous exchanges among individuals. So long as nobody is deliberately and physically coerced into exchanging goods or selling his or her labour to another and there are no legal barriers discriminating against who can apply for jobs or what can be sold, then the liberal criteria of liberty and equality have been satisfied and the market system can be judged as fair. The inequalities that result from its operation follow no strict pattern. Those who do well cannot be said in any absolute sense necessarily to deserve or merit their success - they have merely been fortunate to be born to rich rather than poor parents, or to have had talents that proved to be marketable. Their entitlement to their wealth rests simply on the right not to be interfered with by others, for what we have obtained through transactions which honour the 
right of each and every individual not to be coerced is rightfully ours. As he puts it, governments have no legitimate grounds for meddling with capitalistic acts between consenting adults.

Just as Rawlsean social liberalism has been taken up by social democrats, so New Right theories such as Nozick's, which offer a neo-classical liberal defence of the free market, have been taken up by conservatives. Indeed, his argument does contain a strong conservative bias, since it rests on an explicitly historical view of justice based on the pattern of distribution that evolves through market exchanges over time. However, Nozick never claims to be a conservative and others with similar views, such as Hayek, explicitly reject the label. As Roger Scruton has pointed out in his book The Meaning of Conservatisrn, Nozick's right-based argument is in direct opposition to the Old Right emphasis on 'the web of obligations by which citizens are bound to each other and the state.' Moreover, although his theory accords best with laissez-faire capitalist society, he draws on the anarchist and utopian traditions to suggest that it could be compatible with any form of social organization provided it was voluntarily entered into. In common with other contemporary liberal thinkers, the central commitment of his theory is to a pluralist framework which provides scope for people to live according to diverse conceptions of the good.

How convincing are these two versions of liberalism? Once we leave the Rawlsean 'original position', for example, and discover who and where we are, what would motivate us to adhere to the two principles if they appeared to conflict with our most important ideals or interests? Surely, only someone who had swallowed a good dose of liberalism in the first place would feel at all inclined to distance themselves from their cherished beliefs and social and material attachments in the way Rawls' theory requires. Similarly, Nozick offers no reasons for why we have certain rights rather than others, while his defence of Locke's 'labour mixing' theory of property ownership rests on a dubious metaphysics. As so-called left-libertarians, such as Hillel Steiner and Philippe van Parijis, have noted, if there is no predetermined distribution of land and no reason to believe that — all things being equal — some people deserve more property than others, it makes sense to think of resources as commonly owned. There is no reason to think that first use gives an entitlement to ownership. If so, land remains in common and those who use it 
owe the rest a 'rent'. Nor is it at all clear that either theory will be pluralist in outcome. In other words, neither theory seems to workunless it invokes some of the ethos of earlier versions of liberalism. To the extent that this ethos has proved inadequate, then so are these versions of liberalism.

\subsection{Liberal Ideals in a Non Ideal Society}

For all their philosophical sophistication, such theories seem politically and sociologically naive, greatly exaggerating the possible independence and opportunities available to individuals within complex societies. The division of labour; international markets; the organizational structures of modern economies - from large-scale bureaucratic states to multinational corporations and financial and political institutions such as the IMF and the EU - these and other factors make theories which take as their starting point the autonomous individual agent, capable of making his or her way in the world through talent, effort and voluntary agreements with other individuals appear unrealistic. As a result, liberal philosophy has shifted from offering an idealization of the modern social reality to providing an ideal critique of that reality.

Rawls' last two works that followed up a Theory of Justice - Political Liberalism (1993) and The Law of Peoples (1999) - in many respects mark the transition between these two forms of liberal theorising. In the first, he made plain that his arguments were designed for liberal democratic states and sought to outline their underlying logic and the public attitudes and reasoning citizens and public officials needed to adopt for them to work legitimately. He also suggested that justice should be seen as primarily political and secondarily as social and economic - a means for fairly resolving the many disagreements citizens have about how to shape their collective life. In the second work, he offered a sketch of a theory of international justice which controversially both took the state as the main actor in international affairs and sought to accommodate 'decent' but non-liberal democratic regimes.

These works have been heavily criticized by many who admired A Theory of Justice and had regarded it as a theory of universal and global scope and that applied to individuals rather than to political communities. Rawls' response was that he had aimed at a realistic utopia - a vision that seeks ideal principles for a non-ideal world, not least because of the morally and rationally 
imperfect people who inhabit it. Nevertheless, some believe these works made too many concessions to the status quo, giving too much lee-way to cultural differences and social inequalities in particular. They contend that liberal ideals should produce changes in the world rather than simply understanding it, and have sought to deploy his arguments to advocate major reforms to the state system to address global poverty and climate change amongst other issues. However, others believe his realism did not go far enough. They suggest a realistic liberalism takes the inevitability of political conflict as its core, and that a global egalitarianism has to accommodate cultural and social differences, especially when embodied within existing selfgoverning political communities.

\section{Conclusion}

In certain respects, liberalism has become a hegemonic political language. Even those who do not espouse liberal values have a tendency to invoke them by appealing to toleration, equality or rights when seeking a hearing for their views. Yet the pervasiveness of liberal discourse also proves problematic. On the one hand, it produces a plethora of liberalisms, so that it becomes difficult to identify a coherent and generally accepted liberal programme. On the other hand, liberalism can seem either an ideal at odds with the realities of contemporary societies, and as such either unrealized or possibly unrealisable, or as providing current realities with either a justified or spurious legitimation. Liberals and their critics can be found espousing all of these

positions: indeed, even the same individual may voice elements of each of them with regard to different issues. Yet the continuing relevance and interest of liberalism rests on its dual character as both the ideal and reality of modernity, at once its best defence and critique. To be convincing it has to be able both to understand and to change contemporary societies - the challenge confronting liberal theorists is to show it can be both real enough to do the first and ideal enough to achieve the second. 
See also:

American Revolution, The Bureaucracy and Bureaucratization; Civil Liberties and Human Rights; Civil Society, Concept and History of; Conservatism: Historical Aspects; Conservatism:

Theory and Contemporary Political Ideology; Constitutionalism; Dependency Theory; Freedom: Political; French Revolution, The; Individualism versus Collectivism: Philosophical Aspects; Liberalism; Liberalism and War; Liberalism: Historical Aspects; Mill, John Stuart (1806-73); Modernity; Modernity: Anthropological Aspects; Modernity: History of the Concept; Smith, Adam (1723-90); Tolerance; Traditions in Sociology Bibliography

Arblaster, A. (1984). The Rise and Decline of Western Liberalism. Oxford, UK: B Blackwell. Bellamy, R (1992). Liberalism and Modern Society. Cambridge, UK: Polity Press.

Bellamy, R. (1999). Liberalism and Pluralism: Towards a Politics of Compromise. Routledge: London

Bellamy, R. (2000). Rethinking Liberalism. London and New York: Continuum.

De Ruggiero, G. (1927). The History of European Liberalism. Oxford, UK: Oxford University Press.

Gray, J. (1986). Liberalism. Milton Keynes, UK: Open University Press.

Gray, J. (2000). The Two Faces of Liberalism, Cambridge: Polity Press

Seidman, S. (1983). Liberalism and the Origins of European Social Theory. Oxford, UK: B Blackwell. 